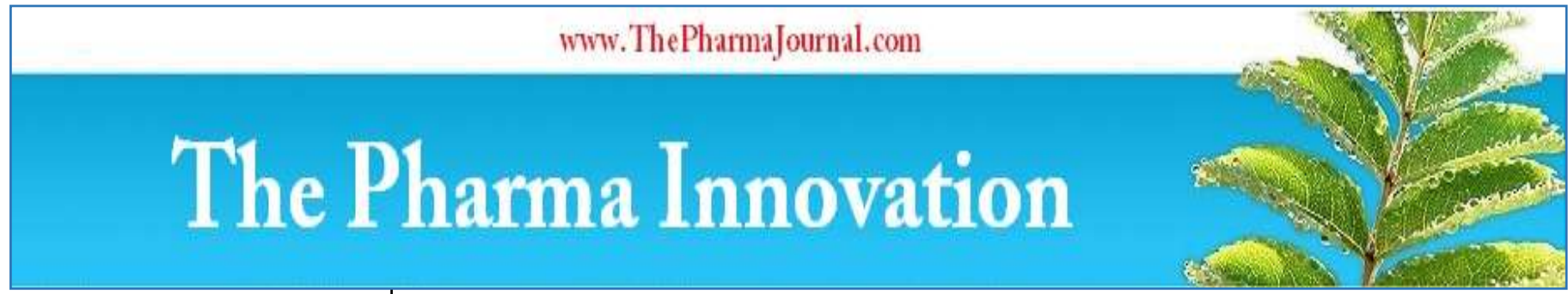

ISSN (E): 2277- 7695

ISSN (P): 2349-8242

NAAS Rating: $\mathbf{5 . 2 3}$

TPI 2021; 10(4): 1185-1191

(C) 2021 TPI

www.thepharmajournal.com

Received: 17-02-2021

Accepted: 23-03-2021

\section{Jashanveer Kaur}

Lovely Faculty of Technology

and Sciences, Lovely

Professional University,

Phagwara, Punjab, India

\section{Anjan Borah}

Lovely Faculty of Technology

and Sciences, Lovely

Professional University,

Phagwara, Punjab, India
Corresponding Author: Anjan Borah

Lovely Faculty of Technology

and Sciences, Lovely

Professional University,

Phagwara, Punjab, India

\section{Application of bacteriocins and Aloe vera gel as biopreservatives in edible coatings to extend the shelf life of fruits and vegetables: A review}

\author{
Jashanveer Kaur and Anjan Borah
}

DOI: https://doi.org/10.22271/tpi.2021.v10.i4q.6176

\section{Abstract}

The freshness of fruits and vegetables prevails for a very less time, as they continue to respire and occurrence of exchange od gases, solutes and other metabolic activities goes on after harvesting. So, the need of post-harvest is very much required to enhance their shelf life. Edible coating are defined as a very fine layer of substance made over the surface that can be eaten along, it works by modifying the environment surrounding the food commodity. It controls the exchange of gases and other metabolic processes thus helps the fruits and vegetable to perpetuates the freshness for extended period of time. The use of chemical preservatives is becoming less and less obvious with the increase in consumer awareness. So, bio preservation has gained a lot of attention. Bio preservation refers to the use of microorganism or plants or their substances to improve the shelf life. Bacteriocin produced by lactic acid bacteria are GRAS certified and have shown considerable antimicrobial effects against different food borne pathogens. Aloe vera gel is plant derived and do have antimicrobial activities and has shown a noticeable success for the extension of shelf life of fruits and vegetables.

Keywords: Edible coatings, Aloe vera gel, bacteriocins, shelf-life extension, antimicrobial, lactic acid bacteria, bio preservation

\section{Introduction}

Fruits and Vegetables (F\&V) are imperative for good physical and mental health. They make crucial components of the balanced diet (Brookie, Best and Conner, 2018) ${ }^{[10]}$. F\&V contain ample amount of all the vital nutrients such as vitamins, minerals, organic acids, antioxidants and polyphenols. People having F\&V in diets in a considerable amount are known to be less prone to certain diseases such as diabetes, obesity, cardiovascular diseases, and some type of cancer (Volpe, Cavella \& Torrieri, 2019) ${ }^{[64]}$. Fruit and vegetable spoilage is affected by the number of external factors (Valdes et al., 2017) ${ }^{[62]}$. Post-harvest contamination could originate from microbial, physical or physiological sources (Palou, Valencia-Chamorro \& Perez-Gago, 2015) ${ }^{[54]}$. Fresh fruits are usually accounted as microbiologically safe for consumption. However, they get contaminated due to various reasons such as air, irrigation water, animals and during harvest and post-harvest (Iglesias et al., 2018) ${ }^{[29]}$. Intrinsic factors such as sugars, water activity, $\mathrm{pH}$, enzymatic activity play critical role in microbial growth and degradation of fruits and vegetables (Fan and Song, 2013) ${ }^{[21]}$. With the passing time overall quality of the fruit start getting worse affecting the flavor, visual and nutritional attributes (Nunes \& Emond, $2007)^{[48]}$. Fruits are easily spoiled because of its high-water content; loss of water affects the nutritional profile makes the fruit look mushy results in flabbiness and withering. Various Post harvest treatments such as Controlled atmosphere packaging (CAP), Modified atmosphere packaging (MAP) and edible coatings which works on the principle of suppressing the rate of the metabolic processes taking place in fruits and vegetable to enhance the shelf life. These treatments lower the rate of the respiration and transpiration, eventually resulting in the gradual decrease in the moisture loss (Dhall, 2013) ${ }^{[18]}$.

An Edible coating is widely used ongoing method for the extension and improvement of the shelf-life of the vegetables and fruits that work as an obstacle against the exchange of gases, moisture loss and microbial attacks by manipulating the environment inside the food stuff (Chiabrando and Giacalone, 2016; Puttalingamma, 2013) ${ }^{[14,56]}$. An edible coating having antimicrobial characteristics are applied to fruits by using proteins, lipids or polysaccharides biopolymers (Valdes et al., 2017). An optimal consumable coating is that which does not totally block exchange of gases but delay the degradation process with minimal effect on the 
quality of the product. This edible coating controls the change in the aroma, water content, taste, exchange of oxygen and carbon dioxide from the eatables (Athmaselvi, Sumitha \& Revathy, 2013) ${ }^{[6]}$. The formation of an edible film could be foccused on fruit wax, fruit (apple puree), vegetable starch (pumpkin), gum Arabic, gum cordia, chitosan, pectin, carboxymethyl cellulose, whey protein isolate, alginate, and Aloe vera gel with antimicrobial properties (Mohapatra et al., 2013) ${ }^{[41]}$.

A new and effective technique is gaining popularity to extend shelf life of fruits and vegetables i.e., bio preservation. It refers to the tactics that are executed to extend shelf life and improve food safety by friendly microorganisms or their products or any plant-based compounds such as mucilages, essential oils etc. It is also fairly accepted by consumers due to its total natural ingredients and research is rapidly engaged in the field of bio preservation (Narsaiah et al., 2014; Sharma et al., 2011) ${ }^{[47,59]}$.

Bacteriocins are the antimicrobial compounds that are produced by lactic acid bacteria (Ghanbari et al., 2013) ${ }^{[22]}$. Lactic acid bacteria (LAB) are Gram positive rods or cocci, non-aerobic but aerotolerant, they can ferment carbohydrates for energy and Lactic acid production (Prada et al., 2007) ${ }^{[54]}$. LAB has the GRAS (Generally Regarded as Safe) status. Bacteriocins produced by $\mathrm{LAB}$ are rapidly degraded by human digestive enzymes due to which they have immense potential in food safety and preservation (Ghanbari et al., 2013) ${ }^{[22]}$. Most common genera that used for bacteriocins production are; Carnobacterium, Lactobacillus, Lactococcus, Leuconostoc, Pediococcus and streptococcus (Altuntas, 2013) ${ }^{[5]}$. A variety of bacteriocins has been purified and found to show bacteriostatic and bacteriocidal activity against different food deteriorating and pathogenic microbes (Jeevaratnam, Jamuna and Bawa, 2005) ${ }^{[30]}$.

The antibacterial activity of acidocin B produced by Lactobacillus acidophilus and Plantaracin

Aloe vera (AV) gel contains huge number of bioactive compounds such as antioxidants, mannans, lectine, antron etc. It is also environment friendly (Ergun and Satici, 2012) ${ }^{[20]}$. AV gel is also found to be nutrient rich; it contains vitamins, amino acids, minerals, sugars and enzymes (Mohebbi et al., 2012) ${ }^{[42]}$ and has wide applications in fruits and vegetable preservation. AV gel has been used as coating material for sweet cherry (Martinez-Romero., 2006) [38], tomatoes (Chauhan et al., 2015; Kumar et al., 2018) [12, 33], and table grapes (Valverde et al., 2005) ${ }^{[63]}$ to extend their shelf life. AV gel has been used in combination with other components such as AV gel and ascorbic acid for strawberries and AV gel and shellac is used in synergism to extend shelf-life tomatoes (Chauhan et al., 2015) ${ }^{[12]}$.

\section{Edible Coatings}

An edible coating can be defined as a very fine semipermeable layer of substance that can be eaten along made over the surface of fruit and vegetable with purpose to maintain its quality for longer period of time. These days edible coating have gathered enough attention because of various disadvantages related to the synthetic coating (Delgani, Hosseeini and Regenstein, 2017) ${ }^{[17] . ~ E d i b l e ~}$ coatings work on the same principle to that of modified atmosphere packaging (MAP). It modifies the internal environment of the fruit and vegetable by altering the rates of various metabolic processes and moisture loss. Edible coating functions as an obstacle against the movement of oxygen, carbon dioxide, solutes and moisture. It also prevents the fruits and vegetables from the direct contact with the microbes and works as a protective layer (Hasan et al., 2020; Chaudhary et al., 2020) [24, 11]. The primary focus of edible coating is to protect the product against any biological, physical and mechanical injury (Orgel Zamudio et al., 2017) [52]. An optimal consumable coating is that which does not totally block exchange of gases but delay the degradation process with minimal effect on the quality of the product. The edible coating controls the change in the aroma, water content, taste, exchange of oxygen and carbon dioxide from the eatables (Athmaselvi et al., 2012) ${ }^{[6]}$.

The effectiveness and the stability of the edible will rely on its composition. The most common components of the edible coating are basically obtained from the natural sources, and can be categorized into polysaccharides, proteins, lipids and composites (blend of one or more of these biolpolymers) (Dhall, 2013; Mannozi et al., 2017) [18, 37]. Among polysaccharides cellulose, chitosan, starch, pectin, pullulan, and different gums have been used. There are enough number of researches where different proteins such as gelatin, corn zein, wheat gluten, whey protein and albumen have been used. Same applies for the lipids and studies are available for the application of various waxes, fatty acids, acetoglycerides are available. The application of edible coating is performed by spraying, dipping, brushing and extrusion method. Dipping and brushing remain the most favored methods while other two are used only at some special cases only (Raghav, Agarwal and Siani, 2016) ${ }^{[57]}$. Edible coatings can be enriched with or composed of variety of antimicrobial compounds, antimicrobial agents, colorants, flavoring compounds, nutrients and essential oils from spices and herbs (Hassan et al., 2018 ; Tesfaye et al., 2017) ${ }^{[25,60]}$.

\section{Biopreservation}

The term bio preservation refers to the techniques that are executed to extend shelf life and improve food safety by friendly microorganisms or their products. Increasing awareness regarding food safety has elevated concern among consumers. The implementation of biological methods to preserve the food is more acceptable approach to reduce the risk of food born ailments arise due to deterioration of food by microorganisms and to satisfy the consumers (Aluntas, 2013) ${ }^{[5]}$.

\section{Lactic Acid Bacteria}

Lactic acid bacteria are a large group of bacteria that belongs to phylum firmicutes. These are Gram positive cocci or rod shaped strictly fermentative but aero tolerant microorganisms (de Macedo et al., 2013) ${ }^{[15]}$. Based on metabolic pathway LABs are categorized into homofermentative and heterofermentative types. The homofermentative LABs comprises Lactobacillus, Lactococcus, Pediococcus and Streptococcus species that produce two molecules of lactate for each molecule of glucose consumed via EMP pathway while heterofermentative LABs produce variety of products where carbon dioxide, ethanol and lactate are the major products. Species of Leuconostoc and Weisella are included in this category and majorly they metabolize sugars via 6phosphogluconate/phosphoketolase pathway (Hitendra et al., 2016) ${ }^{[27]}$. Lactic acid bacteria are known to produce bacteriostatic and bactericidal agents that have different modes of actions. Lactic acid and acetic acid production lower the $\mathrm{pH}$ of the food that restricts the growth of many 
mesophilic bacteria. LABs have antagonist character because they synthesize bacteriocins and non-proteinaceous low molecular mass compounds (LMMC) which have antimicrobial properties (Hitendra et al., 2016) ${ }^{[27]}$.

\section{Bacteriocins}

Bacteriocins are ribosomally synthesized antimicrobial peptides that vary in structure and are released extracellularly. Bacteriocins are rapidly hydrolyzed by proteases in the human digestive tract thus they are in generally regarded as safe (GRAS) by US FDA and can be used in food preservation (Naidu et al., 2006; O'Connor et al., 2020) [46, 50]. Most commonly used genera for the production of bacteriocins are Carnobacterium, Enterococcus, Lactobacillus, Lactococcus, Leuconostoc, Pediococcus and Propionibacterium. For the preservation of food products different bacteriocins are employed individually or in combination of two or more. Amongst many bacteriocins only few are tested for preservation of fruits and vegetables such as bificin, bovicin, enterocin, nisin and pediocin (de Souza Barbosa et al., 2015) [16]. Adequate amount of data is available for the use of bacteriocins as food additives but little amount of data is available regarding the edible coating of bacteriocins (Narsaiah et al., 2015) ${ }^{[47]}$.

Bacteriocins produced by LABs are mostly cationic, hydrophobic or amphiphilic and heat stable peptides having 20 to 60 amino acid residues (Naidu et al., 2006) ${ }^{[46]}$. The bacteriocins are classified into four classes. Class I (Lantibiotics) they act by creating pores in bacterial membranes or by inhibiting some specific enzymes, Nisin, ancovenin, cinnamycin and duramycin are are the few examples of this class (O'Connor et al., 2020; Naidu et al., 2006) ${ }^{[50,46]}$. Class II (Non-lantibiotics) also known as small heat stable peptides. Potent anti-listerial activity is main feature of class II bacteriocins. Class II bacteriocins are further divided into class IIa to IIe. Pediocin, enterocin, diversin V41, plantaracin, sakacins, carnobacteriocin A and enterocin B all belong to this class (Naidu et al., 2006). Class III (Large Heat Labile Proteins) have size greater than $30 \mathrm{kDa}$ and are heat labile. Not much information is available regarding the characteristics of these bacteriocins. Helvetin and enteroysin that are produced by Lactobacillus helveticus and Enterococcus faecium respectively ( Kumariya et al., 2019; Naidu et al., 2006) ${ }^{[35,46] .}$

Class IV (Complex Proteins) consists of lipoproteins or glycoproteins which require nonprotein compounds for antimicrobial activity (Kumariya et al., 2019; Naidu et al., 2006) ${ }^{[35,46]}$.

\section{Mode of Action of Bacteriocins}

Antibacterial peptides produced by bacteria provide immunity and defense against pathogenic bacteria. Although mechanism of bacteriostatic and bactericidal activity of every class differs from each other but all the bacteriocins are more effective against Gram positive bacteria than Gram negative bacteria due to the presence of external membrane which inhibit the action (Kumariya et al., 2019; Parada et al., 2007) ${ }^{[35,54] .}$

Different mechanisms include pore formation, inhibition of spore germination and altering enzymatic activity. It has been observed that for many bacteriocins the primary target is cytoplasmic membrane of the sensitive cells where they perform the disruption of the protein motif force (PMF) through the short lived, non-selective transmembrane pores that leads to the release of intracellular fluid and results in the death of the cell (Xu et al., 2020; Ibarra-Sanchez et al., 2020) $[65,28]$.

\section{Bacteriocin as bio preservative}

Antimicrobial properties of the lactic acid bacteria (LAB) allied to their safe use in traditional fermented foods; this makes them very attractive to be used as bio preservative (O’Connor et al., 2020) ${ }^{[50]}$. Bacteriocins produced by LAB have potent industrial applications, since majority of bacteriocins producing LAB are natural food isolates, so they are well suited for food applications (Gong et al., 2010) ${ }^{[23]}$. Bacteriocin-producing LAB are found to be highly potent in the bio preservation of foods of plant origin, especially minimally processed foods such as prepackaged mixed salads and fermented vegetables. Among various bacteriocins of LAB nisin $A$ and its natural variant nisin $\mathrm{Z}$ has been effective against microorganisms causing spoilage (Zacharof \& Lovitt, 2012) ${ }^{[66] .}$

Shelf life of fresh papayas has increased by 2-21 days when pediocin produced by Pediococcus pentosaceus was used in combination with $2 \%$ alginate for coating (Narsaiah et al., 2015) ${ }^{[47]}$.

The effect of enterocin AS-48 on Listeria monocytogenes CECT 4032 was studied on various fruits stored at temperatures $-20,6,15,22^{\circ}$ C. Enterocin AS-48 fully inactivated L. monocytogenes in the blackberries, raspberries and strawberries for 2 days at temperature 15 and $22{ }^{\circ} \mathrm{C}$ and for 7 days in blackberries and strawberries stored at $6{ }^{\circ} \mathrm{C}$. It also resulted in the reduction of viable count of sliced melon, water melon, kiwi and pears (Molinos et al., 2008a) ${ }^{[44]}$.

Minimally processed Mangoes were tested against Listeria monocytogenes and Staphylococcus aureus using Nisin incorporated cellulose film. After 4 days L. monocytogenes count decreased below the detection level and reduction of 6 $\log$ units was observed for S.aureus. However, both the samples were initially inoculated with $107 \mathrm{CFU} / \mathrm{g}$ of viable cells of S.aureus and L.monocytogenes (Barbosa et al., 2013) [7].

Enterocin AS-48 tested for the decontamination of Bacillus cereus and Bacillus weihenstephanesis on various raw vegetables such as Alfalfa, green asparagus, and soybean sprouts. After washing vegetables with enteriocin AS-48 solution, the microbial count was decreased by 1.0-1.5 and 1.5-2.38 log units respectively for B.cereus and $B$. weihenstephanesis. During further storage at $6^{\circ} \mathrm{C}$ the bacteriocin was able to reduce the viable population below the detection level (Molinos et al., 2008b) ${ }^{[45]}$.

Tumbarski et al., (2020) [61] studied the effectiveness of Bacillus methylotrophicus BM47 bacteriocin in the pectin based edible coating for the shelf life extension of fresh blueberries. Fruits were analyzed for the change in Titratable acidity, total soluble sugars, $\mathrm{pH}$, decay percentage, antioxidant and total phenols over the storage of 16 days at $4^{\circ}$ $\mathrm{C}$ and $75 \% \mathrm{RH}$. Coating was found to be effective in reducing the decay percentage, weight loss and total soluble sugars. However, no effect was noted down on the $\mathrm{pH}$, antioxidant and total phenols due to pectin + bacteriocin coating. 
Table 1: Application of bacteriocin on different fruits and vegetables

\begin{tabular}{|c|c|c|c|c|c|c|}
\hline $\begin{array}{l}\text { S. } \\
\text { No. }\end{array}$ & Bacteriocin & $\begin{array}{c}\text { Source } \\
\text { microbe }\end{array}$ & Fruits \& Vegetable & $\begin{array}{c}\text { Storage } \\
\text { temp. }\left({ }^{\circ} \mathrm{C}\right)\end{array}$ & Observations \& Results & References \\
\hline 1. & $\begin{array}{l}\text { Enterocin } \\
\text { AS- } 48\end{array}$ & $\begin{array}{l}\text { Enterococcus } \\
\text { faecalis }\end{array}$ & $\begin{array}{c}\text { Blackberries, Raspberries, } \\
\text { Strawberries, Melons }\end{array}$ & $\begin{array}{l}-20,6 \\
15,22 \\
\end{array}$ & $\begin{array}{c}\text { Inactivation of Listeria } \\
\text { monocytogenes, increase in shelf life }\end{array}$ & $\begin{array}{l}\text { Molinos et } \\
\text { al. (2008a) }\end{array}$ \\
\hline 2. & $\begin{array}{l}\text { Enterocin } \\
\text { AS48 }\end{array}$ & $\begin{array}{l}\text { Enterococcus } \\
\text { faecalis }\end{array}$ & $\begin{array}{c}\text { Alfalfa, green asparagus, } \\
\text { soybean sprouts }\end{array}$ & 6 & $\begin{array}{c}\text { Reduction in the count of B.cereus and } \\
\text { B.weihenstephanesis }\end{array}$ & $\begin{array}{l}\text { Molinos et } \\
\text { al. }(2008 \mathrm{~b})\end{array}$ \\
\hline 3. & Nisin & $\begin{array}{c}\text { Lactococcus } \\
\text { lactis }\end{array}$ & Mango & 5 & $\begin{array}{c}\text { Reduced the count of } \\
\text { L.monocytogenes and S.aureus }\end{array}$ & $\begin{array}{l}\text { Barbosa } \text { et } \\
\text { al. }(2013)\end{array}$ \\
\hline 4. & Pediocin & $\begin{array}{l}\text { Pediococcus } \\
\text { spp. }\end{array}$ & Papaya & 4 & Increased shelf life from 2 to 21 days & $\begin{array}{l}\text { Narsaiah et } \\
\text { al. (2015) }\end{array}$ \\
\hline 5. & Bacteriocin & $\begin{array}{l}\text { Lactobacillus } \\
\text { acidophilus }\end{array}$ & Apple & 25 & $\begin{array}{l}\text { Inhibition of microbial spoilage, } \\
\text { maintained physiochemical } \\
\text { properties }\end{array}$ & $\begin{array}{l}\text { Bhatia et al. } \\
\quad \text { (2016) }\end{array}$ \\
\hline 6. & Nisin & $\begin{array}{l}\text { Lactobacillus } \\
\text { Lactis }\end{array}$ & Tomato & $\begin{array}{l}4,10 \\
\text { and } 25\end{array}$ & $\begin{array}{l}\text { Inhibited the growth of Listeria } \\
\text { monocytogenes }\end{array}$ & $\begin{array}{l}\text { Oladunjoye } \\
\text { et al. (2017) }\end{array}$ \\
\hline
\end{tabular}

\section{Aloe vera Gel}

Plant based edible coatings are contemplated as safe and compelling alternative for enhancement of the shelf life and quality preservance. These coatings successfully obstruct the loss of weight and exchange of gases (Mahajan et al., 2018) [36].

Aloe is a tropical or subtropical plant. That is usually characterized by lance shaped leaves with jagged edges and sharp points. Aloe vera gel is resinous material obtained from aloe plant (Aloe barbadensis Miller). Aloe vera gel has multidimensional applications. Aloe vera gel is gifted a vast resource of carbohydrates in form of glucomannans, antioxidants and secondary metabolites with biopreservative functionality. The Aloe vera gel has moisture conditioning and biopreservative properties which are required for formulating edible surface coating (Chauhan, Gupta \& Agarwal, 2014) ${ }^{[13]}$. Aloe vera gel coatings are also known to impede the activity of various enzymes such as polyphenol oxidases and peroxidases, it also reduces the chances of phenolic oxidation and browning. Aloe vera gel is made up of number of components such as polysaccharides, salicyclic acid, amino acids, glycoproteins, vitamins, phenolic compounds and enzymes. It exhibits antifungal, antibacterial and anti-inflammatory properties (Kumar and Bhatnagar, 2014) ${ }^{[34]}$.

Parenchyma cells of leaves include mucilaginous clear gel, which is applied as Aloe vera gel. Aloe vera gel contains number of nutrients such as vitamins, fatty acids, sugars, minerals and various enzymes; therefore, it is used as functional ingredient for health benefits. The gel acts as barrier to oxygen and carbon dioxide, and moisture, thus decreases the consequences of weight loss, browning, softening, and growth of yeast and mold. The presence of number of antimicrobial compounds in the gel makes it prevent the decay (Valverde et al., 2005) ${ }^{[63]}$. The preservative action of Aloe vera gel coating has been reported for Mango (Shah and Hashmi, 2020) [58], Litchi (Ali et al., 2019) [2], Sapodilla fruit (Khaliq, Ramzan \& Balouch, 2019) ${ }^{[32]}$, Lotus root slices (Ali et al., 2019) ${ }^{[3]}$ and Peach (Hazrati et al., 2017) [26] alone or in combination with other additives. "Granny Smith" apples coated with Aloe vera gel (5\% and 10\%) has shown effective results by reducing weight loss, delaying the reduction in soluble solids and titratable acidity and impending change in their appearance (Ergun and Satici, 2012) ${ }^{[20]}$. Different concentrations Aloe vera gels were used for sweet cherry, tomatoes, and table grapes to extend their shelf life and maintain their quality parameters (MartinezRomero., 2006; Chauhan et al., 2015; Valverde et al., 2005) $[38,12,63]$.
Parven et al., (2020) ${ }^{[55]}$, studied the effect of Aloe vera gel as an edible coating to prolong the shelf life of papaya with and without polythene bags stored at temperature of $25 \pm 2^{\circ} \mathrm{C}$ and $80-85 \%$ of relative humidity. Results depicted that Aloe vera gel alone without the polythene bag was found to be most effective in prolonging the shelf life of the papaya up to 14 days. Aloe vera gel coating not only delayed the process of color development but also there was less loss in the weight loss and moisture content by $13.2 \%$ and $28 \%$ after 12 days of the storage. There was reduction in total soluble solids by $3 \%$ and disease severity got reduced by $29 \%$. Fruits coated with Aloe vera gel and stored in the polyethene bags experienced the drastic quality loss, so it should be avoided.

Mohammadi et al., (2020) ${ }^{[40]}$, investigated the effect of Aloe vera gel coating solely and in conjugation with two concentrations of basil oil at $500 \mu \mathrm{L} / \mathrm{L}$ and $1000 \mu \mathrm{L} / \mathrm{L}$ on the shelf life of strawberries stored at temperature of $4^{\circ} \mathrm{C}$ and relative humidity of $85 \%$ for up to 12 days. All the coatings successfully reduced the rate of weight loss, fungal growth and rate of softening of the fruit. Other attributes such as hue color, sensory attributes, flavor index and total acidity remain maintained. The effectiveness of the coating was maximum for 1000 basil oil concentration followed by 500 and then Aloe vera gel.

The study was done to investigate the effectiveness of Aloe vera gel coating to extend the shelf life of fig fruit that were stored at $5^{\circ} \mathrm{C}$ for 10 days in the macro perforated bags. The factors considered to evaluate the effectiveness were firmness of the fruit, weight loss and total soluble solids. Results showed that coating maintained and improved the quality of fruit during the period of 7 days storage. The weight and the firmness of fruit were maintained during the storage period (Allegra et al., 2020) ${ }^{[4]}$.

Khaliq et al. (2019) ${ }^{[31]}$, studied the effectiveness of Aloe vera gel enriched with garlic essential oil coating to control the fungal disease anthracnose and the maintenance of quality of banana after harvesting. Fungus Collectotrichum muase is the main causative agent of this disease. Two concentrations of garlic oil $(0.05 \%$ and $0.1 \%)$ were used in combination with Aloe vera gel, and in one case only Aloe vera gel is used as coated. Coating with $0.1 \%$ garlic oil + Aloe vera gel was found to the most effective in controlling the fungal disease, there was decrease in the germination of spores by $91.2 \%$ and mycelial growth by $87.7 \%$ in the 15 days of the storage of banana. Coating resulted in the delay in any changes in Total soluble solids, weight loss, titratable acidity and the firmness loss. However, the total phenolic content and total antioxidant activity witnessed the enhancement in their values. 
Table 2: Application of Aloe vera gel in different edible coatings

\begin{tabular}{|c|c|c|c|c|}
\hline $\begin{array}{l}\text { S. } \\
\text { No. }\end{array}$ & $\begin{array}{l}\text { Fruits \& } \\
\text { vegetable }\end{array}$ & $\begin{array}{c}\text { Storage } \\
\text { Temp. } \\
\left({ }^{\circ} \mathrm{C}\right)\end{array}$ & Observation and Results & References \\
\hline 1. & Table grapes & 1 & $\begin{array}{l}\text { Reduction in weight loss, moisture loss, firmness } \\
\text { loss }\end{array}$ & Valverde et al. (2005) ${ }^{[63]}$ \\
\hline 2. & Sweet Cherry & 10 & $\begin{array}{c}\text { Reduction in microbial population, delay in color } \\
\text { change, softening }\end{array}$ & Martinez- Romero et al. (2006) ${ }^{[38]}$ \\
\hline 3. & $\begin{array}{c}\text { Button } \\
\text { mushroom }\end{array}$ & 10 & Increase in shelf life and maintained hardness. & Mohebbi et al. (2012) ${ }^{[42]}$ \\
\hline 4. & Apples & 2 & Delay in quality losses and increased shelf life & Ergun and Satici. (2012) ${ }^{[20]}$ \\
\hline 5. & Kiwifruit & $4 \pm 1$ & Retention of quality and sensory attributes & Benitez et al. (2013) ${ }^{[8]}$ \\
\hline 6. & Mango & 31 & Prolonged shelf life by delaying ripening & Ajeethan and Mikunthan, $(2016)^{[1]}$ \\
\hline 7. & Cucumber & 34 & Increase in shelf life and consumer acceptance & Nwosu et al. (2016) \\
\hline 8. & Plum & 20 & $\begin{array}{l}\text { Delay in ethylene production and respiration rate } \\
\text { reduction }\end{array}$ & Martinez- Romero et al., (2017) ${ }^{[39]}$ \\
\hline 9. & Tomato & 25 & Prevention in fungal growth, increased shelf life & Kumar et al., 2018 \\
\hline
\end{tabular}

\section{Conclusion}

Edible coatings are renewable, natural and cheap. There are vast variety of substance still unexplored for the fabrication of edible coatings. Keeping in mind about bio preservation, bacteriocins obtained from different microbial strains are not only ecofriendly but have also shown promising results in maintaining the quality and shelf life for prolonged period of time. Aloe vera gel still being the thrust area and lot of studies are carrying out there, but there are still possibilities of exploring the Aloe vera gel with other bio preservation techniques. So there is need to be paid greater attention to bio preservation and development of herbal coatings to avoid the consequences of the chemical preservatives and synthetic edible coatings.

\section{References}

1. Ajeethan N, Mikunthan G. A Simple Bio-preservation Technique to Increase Shelf Life of Ampalavi Mango Fruits Using Aloe vera Gel. Journal of Agricultural Science and Technology B 2016, 424.

2. Ali S, Khan AS, Nawaz A, Anjum MA, Naz S, Ejaz S, Hussain S. Aloe vera gel coating delays postharvest browning and maintains quality of harvested litchi fruit. Postharvest Biology and Technology 2019;157:110960.

3. Ali S, Khan AS, Anjum MA, Nawaz A, Naz S, Ejaz S et al. Aloe vera gel coating delays post-cut surface browning and maintains quality of cold stored lotus (Nelumbo nucifera Gaertn.) root slices. Scientia Horticulturae 2019;256:108612.

4. Allegra A, Farina V, Inglese P, Alessandra G, Sortino G. Qualitative traits and shelf life of fig fruit (cv Melanzana) treated with Aloe vera gel coating. ACTA Horticulturae 2020;1(1):1-10.

5. Altuntas EG. Bacteriocins: A natural way to combat with pathogens. Microbial Pathogens and Strategies for Combating Them: Science, Technology and Education; Méndez-Vilas, A., Ed. 2013, 1007-15.

6. Athmaselvi KA, Sumitha P, Revathy B. Development of Aloe vera based edible coating for tomato. International Agrophysics 2013;27(4).

7. Barbosa AA, de Araújo HG, Matos PN, Carnelossi MA, de Castro AA. Effects of nisin-incorporated films on the microbiological and physicochemical quality of minimally processed mangoes. International journal of food microbiology 2013;164(2, 3):135-40.
8. Benítez S, Achaerandio I, Sepulcre F, Pujolà M. Aloe vera based edible coatings improve the quality of minimally processed 'Hayward' kiwifruit. Postharvest Biology and Technology 2013;81:29-36.

9. Bhatia A, Rani P, Kaur C. Application of bacteriocin from Lactobacillus acidophilus for shelf-life enhancement of fuji apples. International Journal of Science and Engineering Research 2016;7:775-92.

10. Brookie KL, Best GI, Conner TS. Intake of raw fruits and vegetables is associated with better mental health than intake of processed fruits and vegetables. Frontiers in psychology 2018;10(9):487.

11. Chaudhary S, Kumar S, Kumar V, Sharma R. Chitosan nanoemulsion as advanced edible coatings for fruits and vegetables: Composition, fabrication and developments in last decade. International journal of biological macromolecules 2020;152:154-170.

12. Chauhan OP, Nanjappa C, Ashok N, Ravi N, Roopa N, Raju PS. Shellac and Aloe vera gel based surface coating for shelf life extension of tomatoes. Journal of food science and technology 2015;52(2):1200-5.

13. Chauhan S, Gupta KC, Agrawal M. A new approach of hurdle technology to preserve mango fruit with the application of Aloe vera gel and calcium chloride. International Journal of Current Microbiology and Applied Sciences 2014;3(5):926-934.

14. Chiabrando V, Giacalone G. Effects of edible coatings on quality maintenance of fresh-cut nectarines. Emirates Journal of Food and Agriculture 2016, 201-7.

15. de Macedo RE, Miyague L. Control of Listeria monocytogenes growth by bacteriocin-producing starter cultures in the manufacturing of dry fermented sausage. African Journal of Microbiology Research 2013;7(9):710-8.

16. de Souza Barbosa M, Todorov SD, Ivanova I, Chobert JM, Haertlé T, de Melo Franco BD. Improving safety of salami by application of bacteriocins produced by an autochthonous Lactobacillus curvatus isolate. Food Microbiology 2015;46:254-62.

17. Dehghani S, Hosseini SV, Regenstein JM. Edible films and coatings in seafood preservation: A review. Food chemistry 2018;240:505-513.

18. Dhall RK. Advances in edible coatings for fresh fruits and vegetables: a review. Critical reviews in food science and nutrition 2013;53(5):435-50.

19. Du H, Yang J, Lu X, Lu Z, Bie X, Zhao $\mathrm{H}$ et al. 
Purification, characterization, and mode of action of plantaricin GZ1-27, a novel bacteriocin against Bacillus cereus. Journal of agricultural and food chemistry 2018;66(18):4716-24.

20. Ergun M, Satici F. Use of Aloe vera gel as Biopreservative for "Grany Smith" and "Red Delicious" apples. Journal of Plant and Animal Sciences 2012;22(2):363-368.

21. Fan L, Song J. Antimicrobial microbes-bacteriocin producing lactic acid bacteria. Microbial pathogens and strategies for combating them: science, technology and education. Ed, A Mendez-Vilas. Formatex Research Center, Badajoz. Spain. 2013, 899-909.

22. Ghanbari M, Jami M, Domig KJ, Kneifel W. Seafood biopreservation by lactic acid bacteria-a review. LWTFood Science and Technology 2013;54(2):315-24.

23. Gong HS, Meng XC, Wang H. Mode of action of plantaricin MG, a bacteriocin active against Salmonella typhimurium. Journal of basic microbiology. 2010;50(S1):S37-45.

24. Hasan SK, Ferrentino G, Scampicchio M. Nanoemulsion as advanced edible coatings to preserve the quality of fresh-cut fruits and vegetables: a review. International Journal of Food Science \& Technology 2020;55(1):1-10.

25. Hassan B, Chatha SA, Hussain AI, Zia KM, Akhtar N. Recent advances on polysaccharides, lipids and protein based edible films and coatings: A review. International journal of biological macromolecules 2018;109:1095107.

26. Hazrati S, Kashkooli AB, Habibzadeh F, TahmasebiSarvestani Z, Sadeghi AR. Evaluation of Aloe vera gel as an alternative edible coating for peach fruits during cold storage period. Gesunde Pflanzen 2017;69(3):131-137.

27. Hitendra J, Narotham BD, Prasad G, Suvarna H. Role of lactic acid bacteria (LAB) in food preservation. Int Journal of Current Microbiology and Applied Sciences 2016;5(8):255-7.

28. Ibarra-Sánchez LA, El-Haddad N, Mahmoud D, Miller MJ, Karam L. Invited review: Advances in nisin use for preservation of dairy products. Journal of dairy science 2020;103(3):2041-52.

29. Iglesias MB, Echeverría G, Viñas I, López ML, Abadias M. Biopreservation of fresh-cut pear using Lactobacillus rhamnosus GG and effect on quality and volatile compounds. LWT 2018;1(87):581-8.

30. Jeevaratnam K, Jamuna M, Bawa AS. Biological preservation of foods-Bacteriocins of lactic acid bacteria. Indian Journal of Biotechnology 2005;04(4):446-454.

31. Khaliq G, Abbas HT, Ali I, Waseem M. Aloe vera gel enriched with garlic essential oil effectively controls anthracnose disease and maintains postharvest quality of banana fruit during storage. Horticulture, Environment, and Biotechnology 2019;60(5):659-669.

32. Khaliq G, Ramzan M, Baloch AH. Effect of Aloe vera gel coating enriched with Fagonia indica plant extract on physicochemical and antioxidant activity of sapodilla fruit during postharvest storage. Food chemistry 2019;286:346-353.

33. Kumar JA, Kumar S, Tripti B. Studies to enhance the shelf life of tomato using Aloe vera and neem based herbal coating. Journal of Postharvest Technology 2018;06(2):21- 28.

34. Kumar S, Bhatnagar T. Studies to enhance the shelf life of fruits using Aloe vera based herbal coatings: A review. International Journal of Agriculture and Food Science Technology 2014;5(3):211-218.

35. Kumariya R, Garsa AK, Rajput YS, Sood SK, Akhtar N, Patel S. Bacteriocins: Classification, synthesis, mechanism of action and resistance development in food spoilage causing bacteria. Microbial pathogenesis 2019; 128:171-7.

36. Mahajan BC, Tandon R, Kapoor S, Sidhu MK. Natural coatings for shelf life enhancement and quality maintenance of fresh fruits and vegetables-A review. Journal of Postharvest Technology 2018;6(1):1226.

37. Mannozzi C, Cecchini JP, Tylewicz U, Siroli L, Patrignani F, Lanciotti R et al. Study on the efficacy of edible coatings on quality of blueberry fruits during shelf-life. LWT-Food Science and Technology. 2017;1(85):440-4.

38. Martínez-Romero D, Alburquerque N, Valverde JM, Guillén F, Castillo S, Valero D, Serrano M. Postharvest sweet cherry quality and safety maintenance by Aloe vera treatment: a new edible coating. Postharvest Biology and Technology 2006;39(1):93-100.

39. Martínez-Romero D, Zapata PJ, Guillén F, Serrano M. The addition of rosehip oil to Aloe gels improve their properties as postharvest coatings for maintaining quality in plum. Food Chemistry 2017;217:585-592.

40. Mohammadi L, Ramezanian A, Tanaka F, Tanaka F. Impact of Aloe vera gel coating enriched with basil (Ocimum basilicum L.) essential oil on postharvest quality of strawberry fruit. Journal of Food Measurement and Characterization 2020, 1-10.

41. Mohapatra D, Mishra S, Giri S, Kar A. Application of hurdles for extending the shelf life of fresh fruits. Trends in Post-Harvest Technology 2013;1(1):37-54.

42. Mohebbi M, Hasanpour N, Ansarifar E, Amiryousefi MR. Physicochemical properties of bell pepper and kinetics of its color change influenced by Aloe vera and gum tragacanth coatings during storage at different temperatures. Journal of food processing and preservation 2012;38(2):684-693

43. Mokoena MP. Lactic acid bacteria and their bacteriocins: classification, biosynthesis and applications against uropathogens: a mini-review. Molecules 2017; 22(8): 1255 .

44. Molinos AC, Abriouel H, Ben Omar N, Lucas R, Valdivia E, Galvez A. Inactivation of Listeria monocytogenes in raw fruits by enterocin AS-48. Journal of food protection 2008;71(12):2460-7.

45. Molinos AC, Abriouel H, López RL, Omar NB, Valdivia E, Gálvez A. Inhibition of Bacillus cereus and Bacillus weihenstephanensis in raw vegetables by application of washing solutions containing enterocin AS-48 alone and in combination with other antimicrobials. Food microbiology 2008;25(6):762-70.

46. Naidu AS, Unal R, Tulpinski J. Bacteriocins: antimicrobial activity and applications. Food Science And Technology-New York-Marcel Dekker 2006;148:1391.

47. Narsaiah K, Wilson RA, Gokul K, Mandge HM, Jha SN, Bhadwal $\mathrm{S}$ et al. Effect of bacteriocin-incorporated alginate coating on shelf-life of minimally processed papaya (Carica papaya L.). Postharvest Biology and Technology 2015;100:212-8.

48. Nunes CN, Emond JP. Relationship between weight loss 
and visual quality of fruits and vegetables. In Proceedings of the Florida State Horticultural Society 2007;120:235245).

49. Nwosu C, Ozumba IC, Onyemezie UC, Bosa SO. Storage stability of cucumber (Cucumis sativus L.) using Aloe vera gel: A preliminary evaluation. International Journal of Multidisciplinary Studies 2016;1(2):15-25.

50. O'Connor PM, Kuniyoshi TM, Oliveira RP, Hill C, Ross RP, Cotter PD. Antimicrobials for food and feed; a bacteriocin perspective. Current opinion in biotechnology 2020;61:160-7.

51. Oladunjoye AO, Singh S, Ijabadeniyi OA. Biocontrol of Listeria monocytogenes ATCC 7644 on fresh-cut tomato (Lycopersicon esculentum) using nisin combined with organic acids. Food science and biotechnology 2016;25(5):1491-6.

52. Oregel-Zamudio E, Angoa-Pérez MV, Oyoque-Salcedo G, Aguilar-González CN, Mena-Violante HG. Effect of candelilla wax edible coatings combined with biocontrol bacteria on strawberry quality during the shelf-life. Scientia Horticulture 2017;214:273-279.

53. Palou L, Valencia-Chamorro SA, Pérez-Gago MB. Antifungal edible coatings for fresh citrus fruit: A review. Coatings 2015;5(4):962-86.

54. Parada JL, Caron CR, Medeiros AB, Soccol CR. Bacteriocins from lactic acid bacteria: purification, properties and use as biopreservatives. Brazilian archives of Biology and Technology 2007;50(3):512-42.

55. Parven A, Sarker MR, Megharaj M, Meftaul IM. Prolonging the shelf life of Papaya (Carica papaya L.) using Aloe vera gel at ambient temperature. Scientia Horticulturae 2020;265:109228.

56. Puttalingamma V. Edible coatings of carnauba wax-a novel method for preservation and extending longevity of fruits and vegetables-A review. International Journal of Food Safety 2014;16:1-5.

57. Raghav PK, Agarwal N, Saini M. Edible coating of fruits and vegetables: a review. IJSRME. 2016;1:188-204.

58. Shah S, Hashmi MS. Chitosan-Aloe vera gel coating delays postharvest decay of mango fruit. Horticulture, Environment, and Biotechnology 2020, 1-11.

59. Sharma N, Kapoor R, Gautam N, Kumari R. Purification and characterization of bacteriocin produced by Bacillus subtilis R75 isolated from fermented chunks of mung bean (Phaseolus radiatus). Food Technology and Biotechnology 2011;49(2):169.

60. Tesfay SZ, Magwaza LS. Evaluating the efficacy of moringa leaf extract, chitosan and carboxymethyl cellulose as edible coatings for enhancing quality and extending postharvest life of avocado (Persea americana Mill.) fruit. Food Packaging and Shelf Life 2017;1(1):408.

61. Tumbarski Y, Petkova N, Todorova M, Ivanov I, Deseva I, Mihaylova D et al. Effects of pectin-based edible coatings containing a bacteriocin of bacillus methylotrophicus bm47 on the quality and storage life of fresh blackberries. Italian Journal of Food Science 2020;32(2).

62. Valdés A, Ramos M, Beltrán A, Jiménez A, Garrigós MC. State of the art of antimicrobial edible coatings for food packaging applications. Coatings 2017;7(4):56.

63. Valverde JM, Valero D, Martínez-Romero D, Guillén F, Castillo S, Serrano M. Novel edible coating based on Aloe vera gel to maintain table grape quality and safety.
Journal of agricultural and food chemistry. 2005;53(20):7807-13.

64. Volpe S, Cavella S, Torrieri E. Biopolymer coatings as alternative to modified atmosphere packaging for shelflife extension of minimally processed apples. Coatings 2019; 9(9):569.

65. $\mathrm{Xu} \mathrm{C,} \mathrm{Fu} \mathrm{Y,} \mathrm{Liu} \mathrm{F,} \mathrm{Liu} \mathrm{Z,} \mathrm{Ma} \mathrm{J,} \mathrm{Jiang} \mathrm{R,} \mathrm{et} \mathrm{al.}$ Purification and antimicrobial mechanism of a novel bacteriocin produced by Lactobacillus rhamnosus 1.0320 . LWT 2021;137:110338.

66. Zacharof MP, Lovitt RW. Bacteriocins produced by lactic acid bacteria a review article. Apcbee Procedia. 2012;2:50-6. 